\title{
ACRL awards for 1994
}

\section{Honoring accomplishments and supporting professional development}

$\mathbf{T}$ he Association of College and Research Libraries awards program recognizes special achievements and outstanding publications and fosters professional development in academic and research librarianship. Is someone you know deserving of special recognition for their contributions to academic and research librarianship? Take a moment to nominate these outstanding individuals so they can get the recognition they deserve. Please review the requirements for each award and note those for which you or a colleague are eligible.

\section{General submission procedures}

Nominations include documentation (a letter) that indicates: 1) your name, address, and phone number, plus the name, address, e-mail address, and phone number of the person you are nominating; 2) narrative supporting the nomination (keeping in mind the award criteria); 3) a current vita.

Individuals may nominate themselves or others. Unless otherwise indicated send nominations and applications to: (Name of the Award), ACRL, 50 E. Huron St., Chicago, IL 60611.

Staff Contact: For a complete list of previous recipients or if you have questions or need help in compiling a nomination contact: Althea Jenkins, (800) 545-2433, ext. 3248, (312) 2803248 , or U55385@uicvm.uic.edu.

\section{ACHIEVEMENT/DISTINGUISHED SERVICE}

\section{Academic or Research Librarian of the Year Award}

This award recognizes an individual member of the library profession who is making an outstanding national or international contribution to academic or research librarianship and library development.

Award: $\$ 3,000$ donated by Baker \& Taylor.
Criteria: Nominees should have demonstrated achievement in such areas as:

1. Service to the organized profession through ACRL and related organizations.

2. Significant and influential research on academic or research library service.

3. Publication of a body of scholarly and/or theoretical writing contributing to academic or research library development.

4. Planning and implementing a library program of such exemplary quality that it has served as a model for others.

Submission procedure: Send eight copies of the nominating package (see general submission procedure above).

Deadline: December 1, 1993.

Previous recipients: William A. Moffett (1993), Carla Stoffle (1992), Richard De Gennaro (1991), Patricia Battin (1990).

\section{Miriam Dudley Bibliographic Instruction Librarian Award}

This award recognizes an individual librarian who has made an especially significant contribution to the advancement of bibliographic instruction in a college or research institution. The award honors Miriam Dudley, whose pioneering efforts in the field of bibliographic instruction led to the formation of the ACRL Bibliographic Instruction Section.

Award: $\$ 1,000$ cash donated by Mountainside Publishing Company on behalf of its publication, Research Strategies: A Journal of Library Concepts and Instruction. The award is administered by the Bibliographic Instruction Section of ACRL.

Criteria: Nominees should have achieved distinction in one or more of the following areas:

1. Planning and implementation of an academic bibliographic instruction program that has served as a model for other programs nationally or regionally.

2. Production of a body of research and publication that has a demonstrable impact on the concepts and methods of teaching and information-seeking strategies in a college or research institution. 
3. Sustained participation in organizations, at the national or regional level, devoted to the promotion and enhancement of academic bibliographic instruction.

4. Promotion, development, and integration of education for bibliographic instruction in ALA-accredited library schools or professional continuing education programs that have served as models for other courses and programs.

Submission procedure: Send nominating package (see general submission procedure above) to: Sharon Mader, Depaul University Libraries, $2350 \mathrm{~N}$. Kenmore, Chicago, IL 60614. Call Sharon if you have questions or need assistance in compiling this nomination. Phone: (312) 362-8066.

Deadline: December 1, 1993.

Previous recipients: Hannelore Rader (1993), Betsy K. Baker (1992), Carla Stoffle (1991), Joan Ormondroyd (1990).

\section{Hugh C. Atkinson Memorial Award}

This award honors the life and accomplishments of Hugh C. Atkinson, one of the major innovators in modern librarianship, and recognizes outstanding achievement (including risk-taking) by academic librarians that has contributed significantly to improvements in the area of library automation, library management, and/or library development or research.

Award: $\$ 2,000$ cash and a citation. This award is funded by an endowment created by divisional, individual, and vendor contributions given in memory of Hugh C. Atkinson. Additional funds are sought to bring the endowment to at least $\$ 100,000$. Send your tax-deductible contributions to: Hugh Atkinson Memorial Award, ACRL/ALA, 50 E. Huron Street, Chicago, IL 60611. The award is jointly sponsored by the ACRL, the Association for Library Collections and Technical Services (ALCTS), the Library Administration and Management Association (LAMA), and the Library and Information Technology Association (LITA), four divisions of the American Library Association.
Eligibility: The nominee must be a librarian employed in a university, college, or community college library in the year prior to application for the award and must have a minimum of five years of professional experience in an academic library.

Criteria: Nominees must have demonstrated achievement (including risk-taking) that has contributed significantly to improvements in the area of library automation, library management, and/or library

development or research.

Submission procedure: See general submission procedures above.

Deadline: December 1, 1993.

Previous recipients: Richard De Gennaro (1993), Miriam Drake (1992), Donald E. Riggs (1991), Russell Shank (1990).

\section{EBSCO Community College Leaming Resources/Library Achievement Awards}

These two annual awards recognize significant achievement in the areas of: 1) programs and 2) leadership.

Award: $\$ 500$ cash for each award plus citations for each award winner are donated by EBSCO Subscription Services.

Eligibility: Individuals or groups from twoyear institutions, as well as the two-year institutions themselves, are eligible to receive awards.

Criteria: Nominees for the program award should demonstrate significant achievement in development of a unique and innovative learning resources/library program. Nominees for the leadership award should demonstrate significant achievement in advocacy of learning resources/library programs or services or leadership in professional organizations that are associated with the mission of community, junior, or technical colleges.

Submission procedure: Nominations should consist of the application form, a narrative letter describing achievements, and any supporting attachments. Send four copies of the nominations to: Lois Marriott, assistant dean for 


\section{Publications}

Now Available

From ACRL

September 1993 


\section{Management}

New!

Preparing for Accreditation

A Handbook for Academic Librarians

by Patricia Ann Sacks and

Sara Lou Whildin

This valuable, step-by-step workbook is designed to assist forwardthinking librarians make the most of the necessary self-study and evaluation processes through planning, organization, staffing, budgeting, evaluation and reporting.

$\$ 18.00,80$.

0-8389-0621-4, 1993

Recruiting the Academic

Library Director: A Companion to the Search Committee Handbook

by Sharon Rogers and Ruth Person

\$18.65; ACRL member \$15.35

0-8389-7484-8, 1991
Measuring Academic Library Performance: A Practical Approach

by Nancy Van House, Beth Weil, and Charles McClure

This easy-to-use set of output measures is designed to assist you in measuring the impact, efficiency, and effectiveness of academic library activities. No specialized training or knowledge of statistics is needed.

The manual is also available with a dbms software package to make data-collection even easier.

\$34.00, 140p. 0-8389-0529-3, 1990; $\$ 75.00$ with self-running database, 0-8389-0542-0, 1991

\section{Clip Notes}

Practical ideas for managing your library's programs and services are contained in ACRL's College Library Information Packets (CLIPNotes). Each CLIP Note provides data and sample documents from college and small university libraries that will assist you in establishing or refining services and operations.

\section{Interlibrary Loan in College Libraries CLIP Note \#16}

Roxann Bustos, comp.

\$34.50; ACRL member \$28.75, 148p. 0-8389-7652-2, 1993
Database Searching in College Libraries CLIP Note \#15

Sarah Pederson, writer and comp. \$29.95; ACRL member \$24.95, 123p. 0-8389-7651-4, 1993

\section{Audiovisual Policies in College Libraries CLIP Note \#14}

Kristine Brancolini, comp. \$21.95; ACRL member \$18.65, 152 p. 0-8389-7495-3, 1991 


\section{College Library Newsletters CLIP Note \#13}

Patricia Smith Butcher and Susan McCarthy Campbell, comps.

\$18.64; ACRL member \$15.35, 154p. 0-8389-7445-7, 1990

\section{Performance Appraisal in} Academic Libraries

CLIP Note \#12

Barbara Williams Jenkins, comp., with the assistance of Mary L. Smalls \$18.64; ACRL member \$15.35, 128p. 0-8389-7444-9, 1990

\section{Collection Development}

Policies For College Libraries

\section{CLIP Note \#11}

Theresa Taborsky, comp.

\$26.35; ACRL member \$21.94, 175p. 0-8389-7295-0, 1989

Annual Reports for College

Libraries

\section{CLIP Note \#10}

Kenneth Oberembt, comp.

\$21.95; ACRL member \$18.75, 135p. 0-8389-7219-5, 1988
Friends of College Libraries CLIP Note \#9

Ronnelle Thompson, comp.

\$18.75; ACRL member \$15.50, 134p. 0-8389-7171-7, 1987

Periodicals in College Libraries CLIP Note \#8

Jamie Webster Hastreiter, Larry

Hardesty, David Henderson, comps.

\$18.75; ACRL member \$15.45, 116p.

0-8389-7143-1, 1987

Mission Statements for College Libraries

CLIP Note \#5

Jamie Webster Hastreiter, Larry Hardesty, David Henderson, comps. \$21.95; ACRL member \$16.50, 107p. 0-8389-6944-5, 1985

\section{Information Access}

New!

Scholarly Communication in an Electronic Environment: Issues for Research Libraries Robert Sidney Martin, editor Any academic librarian in a position to subscribe to, manipulate, or face the administrative issues of electronic media will find a timely base of information in this book.

\$28.99; ACRL member \$24.99, 136p. 0-8389-7686-7, 1993
New!

Abstracting, Information

Retrieval and the Humanities: Providing Access to Historical Literature Publications in Librarianship: No. 48 by Helen R. Tibbo $\$ 35.00,276 \mathrm{p}$. 0-8389-3430-7, 1993 


\section{Special Collections}

New!

Examples to Accompany

Descriptive Cataloging of Rare Books

Prepared by the Bibliographic Standards Committee of the Rare Books and Manuscripts Section

Rare book catalogers use this handbook of cataloging examples to apply the Library of Congress' de- scriptive code for rare books, Descriptive Cataloging of Rare Books. Designed to complement DCRB, 50 MARC-tagged catalog records are shown with facsimiles of title pages and text on the facing pages. Includes a bibliography of useful tools. Fully indexed.

\$29.99, ACRL members \$23.99, 148p. 0-8389-7672-7, 1993

\section{Thesauri for Use in Rare Book and Special Collections Cataloguing}

These thesauri were developed for use in MARC field 655 and 755 .

Each thesaurus provides standardized vocabulary for retrieving items by form and genre or by various physical characteristics which are typically of interest to special collections librarians.

Genre Terms (2nd ed.)

\$21.95; ACRL member \$18.65, 90p. 0-8389-7516-X, 1991

\section{Paper Terms}

\$8.95; ACRL member \$7.50, 52p. 0-8389-7427-9, 1990

\section{Type Evidence}

\$8.95; ACRL member \$7.50, 19 p.

0-8389-7428-7, 1990

Binding Terms

\$11.50; ACRL member \$9.50, 37p.

0-8389-7210-1, 1988

\section{Provenance Evidence}

\$10.50; ACRL member \$8.50, 24p. 0-8389-7239-X, 1988

Printing \& Publishing Evidence \$8.95; ACRL member \$7.50, 28p. 0-8389-7108-3, 1986

\section{Collection Development}

Women's Studies Collection Development Policies

by WSS Collection Development and Bibliography Committee

This unique tool identifies issues and provides models of existing policies. Complete policy statements from 16 university libraries illustrate the range of issues and provide a variety of models. The RLG Conspectus; Women's Studies supplemental guideline, included as an appendix, identifies issues unique to Women's Studies and describes materials and sources.

\$35.95; ACRL member \$29.95, 122p. 0-8389-7596-8, 1992 
Books for College Libraries III

This set covers more than 50,000 titles chosen to represent a core collection of books for four-year college and university libraries. BCL3 is also available on machinereadable tape. Contact ACRL for details.

$\$ 600$. 6v.set.

$\$ 125$ individual volume 0-8389-3353-X, 1988

\section{Directory of Curriculum Materials Centers, 1990}

Donald Osier, Carol Wright, Janet Lawrence, Mary Ellen Collins, Beth Anderson, comps.

This directory includes 272 institutions and covers purpose, hours, staffing, budget, service, and holdings.

\$39.54; ACRL member \$32.94, 240p. 0-8389-7439-2, 1991

\section{Richard Garnett:}

\section{The Scholar and Librarian}

Publications in Librarianship:

No. 46

by Barbara McCrimmin

$\$ 32.00,211 p$.

0-8389-0508-0, 1989
State Education Documents: A State-by-State Directory for Their Acquisition and Use by EBSS Education-Related Government Publications Subcommittee

This directory provides the means to access the large variety of state education documents available from government agencies.

\$21.95; ACRL member \$18.65, 54p. 0-8389-7327-2, 1989

\section{Western European Studies:} Current Research Trends \& Library Resources

Eva Sartori, Ceres Birkhead, John Cullars, John Dillon, Thomas Kilton, editors

Eleven research papers offer thoughtful synthesis, personal insight and information useful for anyone dealing with recent scholarship in Western European studies.

\$32.95; ACRL member \$29.65, 120p. 0-8389-7461-9, 1990

Women's Studies in Western Europe: A Resource Guide Stephen Lehmann and Eva Sartori, editors

\$19.85; ACRL member \$16.50, 129p. 0-8389-7037-0, 1986

\section{Ethnic Studies Reviews}

Publications in this new series from CHOICE are compiled by the editors from reviews previously published in the magazine (volumes 27 through 29, Asian Americans through volume 30). Each collection provides the full text of the CHOICE review and author and title indexes. The editors consider these collections representative of the significant books that CHOICE reviewed in these ethnic areas.

\section{African and African American Studies}

$\$ 22.00$, approximately 750 titles, 152 p.

0-8389-7630-1, 1992

Asian and Asian American Studies

$\$ 20.00,605$ titles, 113p.

0-8389-7691-3, 1993 
Latino Studies

$\$ 20.00,525$ titles, 112p.

0-8389-7631-X, 1992

Native American Studies

$\$ 15.00,278$ titles, 60p.

0-8389-7632-8, 1992
Order from CHOICE, 100 Riverview Center, Middletown, CT 06457.

\section{Bibliographic Instruction}

\section{New!}

Sourcebook of Bibliographic Instruction

by the Editorial Board of the Bibliographic Instruction Section

A working, desk-top tool for new and experienced bibliographic instruction librarians, the Sourcebook is practical and easy-to-use. Five essential topics are covered: learning theory, instructional design, teaching methods, evaluation, and administration.

\$18.99; ACRL member \$16.92, 96p. 0-8389-7673-5, 1993

\section{Learning to Teach: Workshops on Instruction}

A practical guide for bibliographic instruction practitioners and program coordinators, this book is a useful training manual. Nine workshops cover the basics with clear, concise discussions of classroom techniques, new technologies, and instruction in a multicultural environment. This collection of workshops is designed to develop fundamental skills and addresses critical issues in bibliographic instruction.

\$24.99; ACRL member \$21.99, 86p. ISBN: 0-8389-7627-1, 1993
The Evolving Educational Mission of the Library

Betsy Baker \& Mary Ellen Litzinger, editors

This book identifies strategic issues which challenge the development of instructional programs in academic libraries and suggests roles for librarians in the educational processes of their parent institutions. Academic librarians, library school educators, and higher education faculty and administrators will want this book.

\$29.95; ACRL member \$19.95, 202p. 0-8389-7584-4, 1992

Read This First: An Owner's Guide to the New Model Statement of Objectives for Academic Bibliographic Instruction

Carolyn Dusenbury, Monica Fusich, Kathleen Kenny, and Beth Woodard, editors

\$19.75; ACRL member \$16.45, 72p. 0-8389-7548-8, 1991 


\section{Statistics $\mathcal{E}$ Research}

Academic Libraries Achieving Excellence in Higher

Education: Proceedings of the Sixth National Conference of the Association of College and Research Libraries

Thomas Kirk, editor

This publication includes the complete text of provocative presentations by Julian Bona (leader for social change), W. David Penniman (president of the Council on Library Resources), Paul Saffo (technology consultant and futurist), and Catharine R. Stimpson (women's studies scholar and academic administrator). Practical examinations and solutions to current academic library problems are included in 36 program reports and 52 refereed contributed papers. Inspiring and informative, these proceedings reflect the vitality of the conference and the variety of issues explored.

\$49.95; ACRL member \$44.95, 522p. ISBN: 0-8389-7622-0, 1992

Building on the First Century: Proceedings of the Fifth National Conference of the Association of College and Research Libraries

Jan Fennell, editor

\$32.85; ACRL member \$24.25, 320p. 0-8389-7289-6, 1989

Energies for Transition:

Proceedings of the Fourth National Conference of the Association of College and Research Libraries

Danuta A. Nitecki, editor

\$32.85; ACRL member \$24.25, 248p. 0-8389-6976-3, 1986

\section{ACRL University Library} Statistics, 1990-91

Library Research Center, Graduate School of Library \& Information Science, University of Illinois at Urbana-Champaign, comp.

This edition provides data on over 100 participating libraries. The categories of library data collected include: collections, personnel, expenditures, and interlibrary loan. The institutional data elements reported include degrees offered, enrollment size, and faculty size.

\$69.95; ACRL member \$39.95, 80p. 0-8389-7587-9, 1992

ACRL/Historically Black Colleges \& Universities Library Statistics, 1988-89 Robert E. Molyneux, comp. \$35.95; ACRL member \$25.95, 101p. 0-8389-7547-X, 1991

\section{ACRL University Library Statistics, 1988-89 \\ Denise Bedford, comp. \\ \$49.95; ACRL member \$29.95, 79p. 0-8389-7446-5, 1990}

\section{ACRL University Library Statistics, 1987-88 \\ Robert E. Molyneux, comp.}

\$49.95; ACRL member \$29.95, 79p. 0-8389-7288-8, 1989

ACRL Academic Library Statistics, 1978/79-1987/88 (Diskettes)

\$65.95; ACRL member \$53.95 0-8389-7311-C, 1989 
Library Statistics of Colleges \& Universities, 1985; National Summaries, State Summaries, Institutional Tables

Data on 3,000 academic libraries from the 1985 HEGIS study con- ducted by the Center for Education Statistics

\$33.50; ACRL member \$26.45, 140p. 0-8389-7147-4, 1987

\section{News $\mathcal{E}$ Reviews}

\section{Choice}

Book review journal of the Association of College and Research Libraries (ACRL). Eleven issues per year (July/August combined). ISSN: 0009-4978. Available by subscription only, $\$ 160$ per year domestic rate; $\$ 180$ per year foreign rate; single issues $\$ 20.00$ each. Also available as:

\section{Choice-Reviews-on-Cards}

Reviews from each monthly issue of Choice printed on $3 \times 5$ cards. Available to Choice subscribers only for $\$ 245$ per year domestic rate; $\$ 265$ /year foreign rate, sample box $\$ 30.00$. Order either Choice product from: Circulation Department, Choice, 100 Riverview Center, Middletown, CT 06457. (203) 347-6933.

\section{Rare Books and Manuscripts Librarianship}

A journal of theory and practice covering all aspects of special collections librarianship. Two issues / year. ISSN: 0884-450X. Annual subscription price: $\$ 30.00$ U.S.; $\$ 35.00$ for Canada, Mexico, Spain, and other PUAS countries; $\$ 45.00$ for other foriegn countries; single issues $\$ 15.00$ each.
College and Research Libraries

Official journal of the Association of College and Research Libraries. Six bimonthly issues per year. Sent to ACRL members as a perquisite of membership. Also available on subscription, $\$ 50.00$ per year in the U.S.; Canada and Mexico $\$ 55.00$ per year; and all other countries $\$ 60.00$ per year; single issues $\$ 14.00$ each. ISSN: 0010-0870.

\section{College and Research Libraries News}

Official news magazine of the Association of College and Research Libraries. Eleven issues per year (July/August combined). Sent to ACRL members as perquisite of membership. Also available on subscription, $\$ 25.00$ per year in the U.S.; $\$ 30.00$ per year in Canada and other PUAS countries; $\$ 35.00$ per year in other foreign countries; single issues $\$ 6.50$ each. ISSN: 00990086.

\section{College \& Research Libraries and College \& Research}

Libraries News, Index for Volumes 41-50 (1980-89)

\$29.95; ACRL member \$25.95, 180p. 0-8389-7487-2, 1991 


\section{ACRL Approval Plans}

ACRL publications provide practical ideas, tools and methods for: management, bibliographic instruction, special collections, collection development, statistics \& research.

The convenient and cost-cutting ACRL approval order plan provides automatic priority shipping of ACRL's new books at a $20 \%$ discount to ACRL members ( $10 \%$ to non-members).

There are two approval plan categories from which to choose:

Plan P guarantees that you will automatically be sent all new ACRL publications including CLIP Notes.

ACRL publishes approximately 5 to 6 new titles each year.

Plan PC is exclusively for titles in the CLIP Notes (College Library Information Packets) series. CLIP Notes collect data and sample documents from academic libraries to assist librarians in establishing or refining services and operations.

Easy to enroll. Call or write Mary C. Taylor, ACRL program officer, indicating the category you have chosen. (ACRL/ALA, Approval Plan, 50 East Huron Street, Chicago, IL 60611; 1-800-545-2433 ext. 2515). 


\section{Ordering Information}

1. Fill in your shipping and billing addresses.

2. Check the items you wish to order. Indicate a quantity and sub-total. Add appropriate handling charges.

3. Select a method of payment.

4. Mail the order form to:

American Library Association

Order Department

50 East Huron Street

Chicago, IL 60611

For faster, more personal service, call toll-free 1-800-545-2433, Press 7.

Terms of Business. Institutions and individuals may order on account, plus postage and handling. Prepayment should accompany individuals' orders of $\$ 30$ or less. Shipping and handling charges will be added to all orders. All prices are payable in U.S. funds, net 30 days. First price is list price.

Discounts. ALA personal and organizational members are eligible to receive a ten percent (10\%) discount on ACRL materials (except subscription items). To receive the discount, give your membership number, and deduct the discount when preparing your orders. ACRL personal and organizational members receive $10-$ $30 \%$ discount on non-subscription ACRL materials. Look for the ACRL member price in this booklet. 


\begin{tabular}{|c|c|c|}
\hline Price & 0-8389- & Title \\
\hline$\$ 35$ & $3430-7$ & $\begin{array}{l}\text { Abstracting, Info. Retrieval } \\
\text { \& the Humanities PIL \#48 }\end{array}$ \\
\hline$\$ 49.95 / 44.95$ & $7622-0$ & $\begin{array}{l}\text { Academic Lib. Achieving } \\
\text { Excellence }\end{array}$ \\
\hline$\$ 69.95 / 39.95$ & $7587-9$ & ACRL Stats $90 / 91$ \\
\hline$\$ 49.95 / 29.95$ & $7446-5$ & ACRL Stats $1988 / 89$ \\
\hline$\$ 49.95 / 29.95$ & $7288-8$ & ACRL Stats 1987/88 \\
\hline$\$ 65.95 / 53.95$ & $7311-\mathrm{C}$ & $\begin{array}{l}\text { ACRL Stats 78/79-87/88 } \\
\text { (Diskettes) }\end{array}$ \\
\hline$\$ 21.95 / 18.75$ & $7219-5$ & Annual Reports \\
\hline$\$ 21.95 / 18.65$ & $7495-3$ & A-V Policies \\
\hline$\$ 11.50 / 9.50$ & $7210-1$ & Binding Terms \\
\hline$\$ 600$ & $3353-X$ & Books for College Lib. \\
\hline$\$ 32.85 / 24.25$ & $7289-6$ & Building on 1st Century \\
\hline$\$ 26.35 / 21.94$ & $7295-0$ & Collection Dev. Policies \\
\hline$\$ 18.64 / 15.35$ & $7445-7$ & College Lib. Newsletters \\
\hline$\$ 29.95 / 25.95$ & $7487-2$ & C\&RL/News Index \\
\hline$\$ 29.95 / 24.95$ & $7651-4$ & Database Searching \\
\hline$\$ 39.54 / 32.94$ & $7439-2$ & Dir. of Curriculum Centers \\
\hline$\$ 32.85 / 24.25$ & $6976-3$ & Energies for Transition \\
\hline$\$ 29.95 / 19.95$ & $7584-4$ & Evolving Educ. Mission \\
\hline$\$ 29.99 / 23.99$ & $7672-7$ & Examples to Accompany DCRB \\
\hline$\$ 18.75 / 15.50$ & $7171-7$ & Friends of College Lib. \\
\hline$\$ 21.95 / 18.65$ & $7516-X$ & Genre Terms \\
\hline$\$ 35.95 / 25.95$ & $7547-X$ & HBCU Stats $88 / 89$ \\
\hline$\$ 34.50 / 28.75$ & $7652-2$ & Interlibrary Loan \\
\hline$\$ 24.99 / 21.99$ & $7627-1$ & Learning to Teach \\
\hline$\$ 33.50 / 26.45$ & $7147-4$ & Library Statistics 1985 \\
\hline$\$ 34.00$ & $0529-3$ & Measuring Acad. Lib. Perf. \\
\hline$\$ 75.00$ & $0542-0$ & Measuring.. (disk \& book) \\
\hline$\$ 21.95 / 16.50$ & $6944-5$ & Mission Statements \\
\hline$\$ 8.95 / 7.50$ & $7427-9$ & Paper Terms \\
\hline$\$ 18.64 / 15.35$ & $7444-9$ & Performance Appraisal \\
\hline$\$ 18.75 / 15.45$ & $7143-1$ & Periodicals in College Lib. \\
\hline$\$ 18.00$ & $0621-4$ & Preparing for Accreditation \\
\hline$\$ 8.95 / 7.50$ & $7108-3$ & Printing \& Pub. Evidence \\
\hline$\$ 10.50 / 8.50$ & $7239-X$ & Provenance Evidence \\
\hline
\end{tabular}




\begin{tabular}{|c|c|c|c|}
\hline$\square$ & $\$ 19.75 / 16.45$ & $7548-8$ & Read This First \\
\hline$\square$ & $\$ 18.65 / 15.35$ & $7484-8$ & Recruiting Acad. Lib. Dir. \\
\hline$\downarrow$ & $\$ 32.00$ & 0508-0 & Richard Garnett PIL \#46 \\
\hline- & $\$ 28.99 / 24.99$ & $7686-7$ & Scholarly Communication \\
\hline$\square$ & $\$ 18.99 / 16.92$ & $7673-5$ & Sourcebook for BI \\
\hline$\square$ & $\$ 21.95 / 18.65$ & $7327-2$ & State Education Doc. \\
\hline$\square$ & $\$ 8.95 / 7.50$ & $7428-7$ & Type Evidence \\
\hline$[]$. & $\$ 32.95 / 29.65$ & $7461-9$ & Western European Studies \\
\hline$\square$ & $\$ 19.85 / 16.50$ & $7037-0$ & $\begin{array}{l}\text { Women's Studies in West. } \\
\text { Europe }\end{array}$ \\
\hline$\square$ & $\$ 35.95 / 29.95$ & $7596-8$ & $\begin{array}{l}\text { Women's Studies Collection } \\
\text { Dev. Policies }\end{array}$ \\
\hline & \multicolumn{3}{|c|}{ Subtotal } \\
\hline & \multirow{2}{*}{\multicolumn{3}{|c|}{$\begin{array}{ll}\text { Handling charges............ Handling charges } \$ 3.75 \text { up to } \$ 19.99 \\
\text { Total } & \$ 4.75 \text { for } \$ 20 \text { to } \$ 49.99 ; \$ 6.50 \text { for } \$ 50 \\
& \text { to } \$ 74.99 ; \$ 7.50 \text { for } \$ 75 \text { to } \$ 149.99 ; \\
& 5 \% \text { of total order for } \$ 150+.\end{array}$}} \\
\hline & & & \\
\hline
\end{tabular}

Ship to:

Bill to:

Check/money order enclosed

Charge my credit card:

MasterCard

VISA

American Express

Card Number:

Expires: Signature:

Send Invoice (term 30 days)

Signature: 


\section{ACQUISITION PERSPECTIVES}

4. We have established a reputation for accuracy in billing and shipping to your specifications. Invoices arranged alphabetically by author or title. or numerically by purchase order, and separate billing available upon request for Grant Funds. Title II, gifts, etc. Book House error rate last year was less than $1 / 3$ percent.

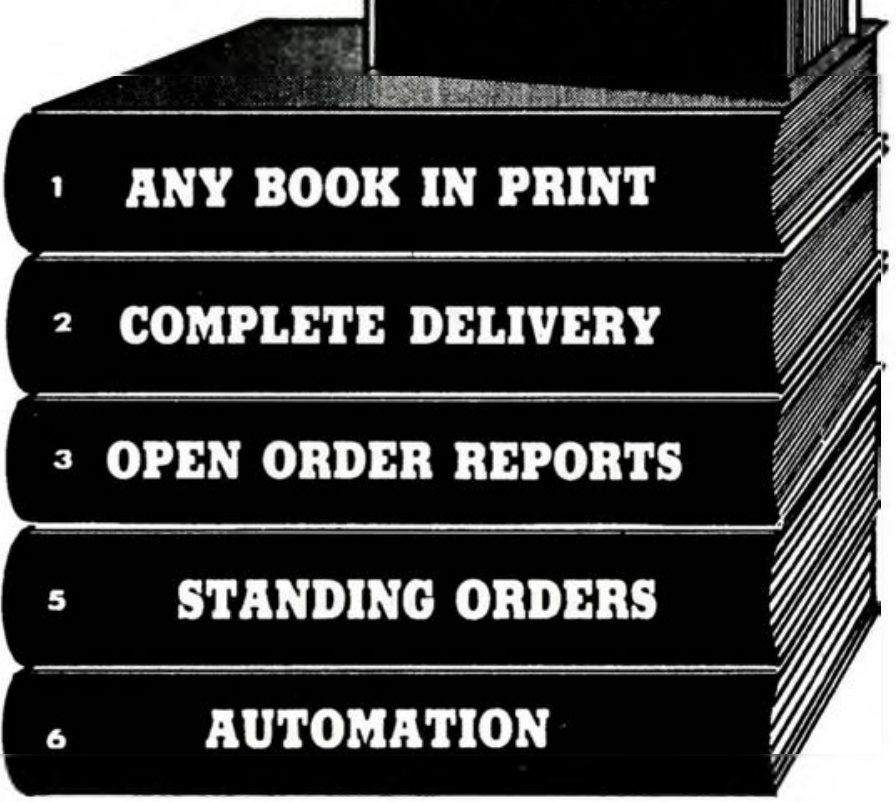

ACCURATE

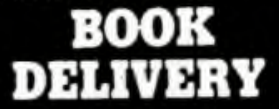

INVOTCED TO YOUR SPECITICATIONS

BOOK HOUSE

the

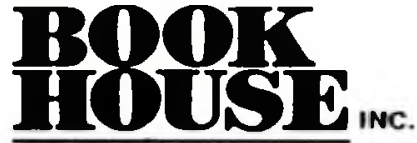

Since 1962

JOEDERS SERYING LIERAFIES WITH ANY UOOK IN PRINT SINCE 10.2 208 WEST CHICAGO STREET

JONESVILLE, MICHIGAN 492500125
Call or Write TODAY

$1 \cdot 800 \cdot 248 \cdot 1146$

FAX: $517 \cdot 849 \cdot 9716$ 
Instructional Resources, Southwestem College, 900 Otay Lakes Road, Chula Vista, CA 91910; (614) 482-6374

Deadline: December 1, 1993.

Previous recipients: Leadership or Community Service: Gloria Terwilliger (1993); Paul E. DuMont (1992); James O. Wallace (1991); Charles R. Peguese (1990). Program Development: Lois Marriott (1993); The Library Collection Development Committee at St. Petersburg Junior College (1992); Jimmie Anne Nourse and Rudy Widman (1991); The Cooperative Collection Development Committee of the Chemeketa Cooperative Regional Library Services (1990).

\section{BIS Innovation in Bibliographic Instruction Award}

This award recognizes and honors librarians who have developed and implemented innovative approaches to bibliographic instruction at their respective institutions.

Award: A citation presented by the BIS Awards Committee at the BIS Annual Conference Program.

Criteria: Recipients must have implemented their ideas recently (within the past two years) in an academic or research library. The emphasis of this award is on creativity and innovation.

Eligibility: There are no restrictions as to the size of the instructional effort, academic discipline, target audience, or techniques employed.

Submission Procedure Applications should be submitted along with the nomination form to the chair of the Innovation Award Subcommittee, Ann Perkins, Public Services Department, CSUN Library, California State University, 18111 Nordheff St., Northridge, CA 91328-1289 (818/885-2277). For further questions or a copy of the nomination form, contact the Subcommittee chair.

Deadline: November 1, 1993

\section{ACRL/EBSS Distinguished Education and Behavioral Sciences Librarian Award}

This award honors a distinguished academic librarian who has made an outstanding contribution as an education and/or behavioral sciences librarian through accomplishments and service to the profession.

Awark A citation presented by the EBSS Award Committee.

Criteria: Nominees should have demon- strated achievements in some of the following areas:

1. Service to the organized profession through ACRL/EBSS and related organizations;

2. Significant academic library service in the areas of education and/or behavioral sciences;

3. Significant research and publication in areas of academic library services in education and/or behavioral sciences;

4. Planning and implementation of academic library programs in education and/or the behavioral sciences disciplines of such exemplary quality that they could serve as a model for others.

The nominee does not have to meet all of the stated criteria.

Submission Procedure: Send ten copies of the award nomination form to Laurene $\mathrm{E}$. Zaporozhetz, Louisiana State University in Shreveport, Noel Memorial Library, One University Place, Shreveport, LA 71115. For questions or to request a copy of the form call Laurene E. Zaporozhetz at (318) 797-5203.

Deadline December 1, 1993.

\section{PROFESSIONAL DEVELOPMENT AND RESEARCH}

\section{Doctoral Dissertation Fellowship}

This award fosters research in academic librarianship by encouraging and assisting doctoral students in the field with their dissertation research.

Award: $\$ 1,000$ cash and citation donated by the Institute for Scientific Information.

Eligibility: The recipient of the fellowship must meet the following qualifications:

1. Be an active doctoral student in the academic librarianship area in a degree-granting institution.

2. Have completed all coursework.

3. Have had a dissertation proposal accepted by the institution.

4. A recipient of the fellowship may not receive it a second time.

5. Applicant need not be an ACRL member.

Criteria: The proposal will be judged primarily on merit with emphasis on the following:

1. Potential significance of the research to the field of academic librarianship. (No attempt will be made to define academic librarianship but the subject should be consistent with topics usually published in College \& Research Libraries or presented at ACRL meetings.)

2. Validity of the methodology and proposed methods of analysis.

3. Originality and creativity. 


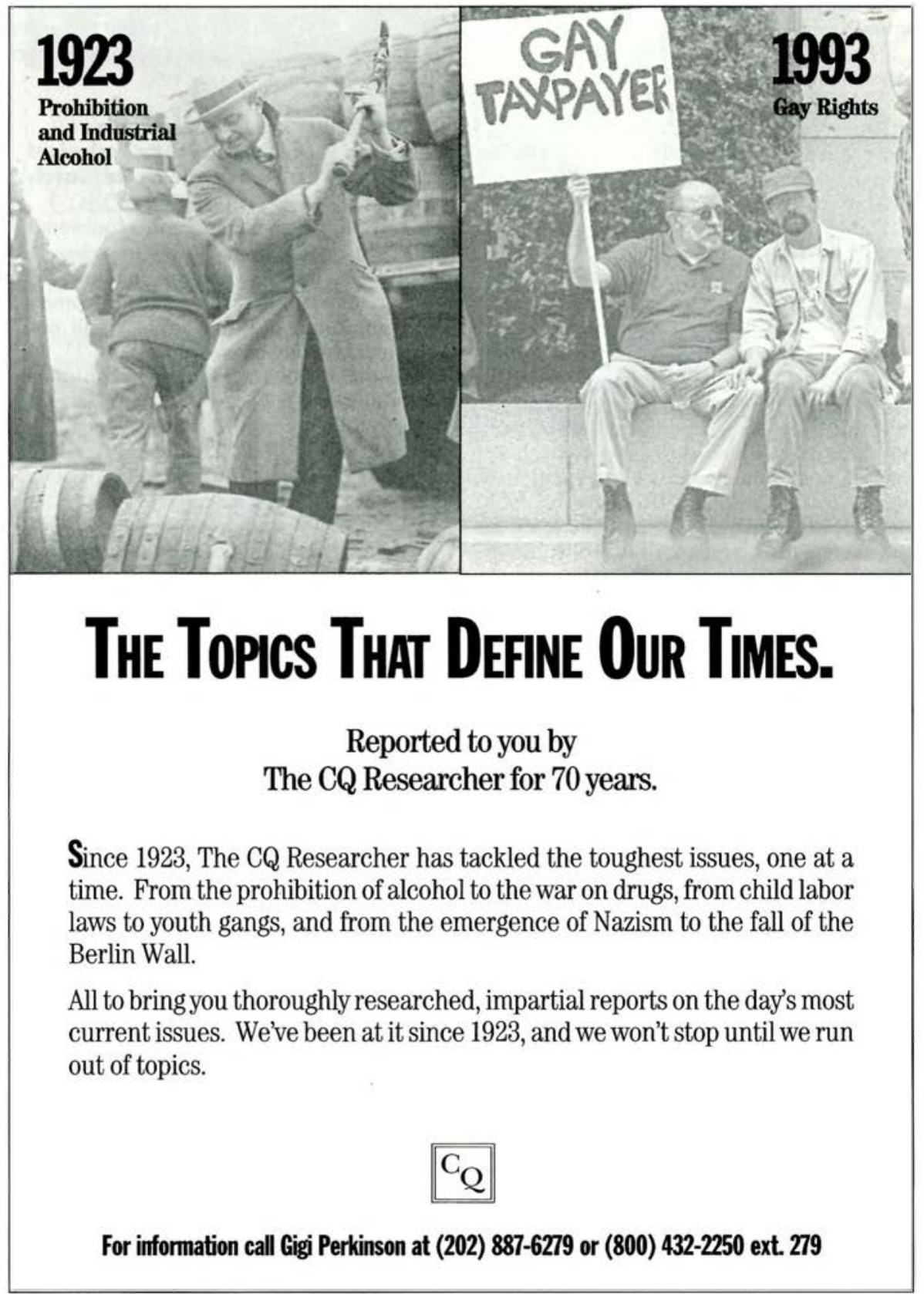


4. Clarity and completeness of the proposal.

5. Presentation of a convincing plan for completion in a reasonable amount of time.

6. Evidence of a continuing interest in scholarship such as a previous publication record.

Submission procedure: Qualified students who wish to be considered for the fellowship should contact the ACRL office for a complete outline of proposal requirements.

Deadline: December 1, 1993.

\section{Martinus Nijhoff International West European Specialist Study Grant}

This grant supports research on Western European studies, librarianship, or the book trade.

Award: A maximum of 10,000 Dutch guilders (or U.S. dollar equivalent) donated by Martinus Nijhoff International, a subscription agent and book dealer with headquarters in The Netherlands. This study grant covers air travel to and from Europe, transportation in Europe, and lodging and board for no more than 14 consecutive days. Funds may not be used for salaries, research-related supplies, publication costs, conference fees, or equipment purchases.

Criteria: The primary criterion for awarding the grant is the significance and utility of the proposed project as a contribution to the study of the acquisition, organization, or use of library materials from or relating to Western Europe. Current or historical subjects may be treated. The award jury will review proposals with the following in mind:

1. What is the work to be accomplished? The proposal should be as explicit as possible about the current state of knowledge in the area and what will be achieved by the successful completion of the study.

2. What is the need for and value of the proposed research? The proposal should provide persuasive evidence that the study is of practical use or scholarly value to the wider community served by the grant.

3. What is the methodology for carrying out the proposed work? The research design should be as specific as possible and demonstrate why the European component is essential.

4. Is the work accomplishable within the time frame proposed? If the study extends beyond the 14-day limit of the grant, the proposal should specify how the additional work will be completed and funded.

5. Are the applicant's qualifications sufficient to carry out the study?
Submission procedure. Librarians who wish to be considered for this study grant should contact the ACRL office to receive full instructions on proposal submission, and grantee obligations.

Deadline: December 1, 1993.

\section{Samuel Lazerow Fellowship for Research in Acquisitions or Technical Services in an Academic or Research Library}

This award fosters advances in acquisitions or technical services by providing librarians a fellowship for travel or writing in those fields. Research projects in collection development or the compilation of bibliographies will not be supported by this fellowship.

Award: $\$ 1,000$ cash and a citation donated by the Institute for Scientific Information.

Criteria: The proposals will be judged with an emphasis on the following:

1. Potential significance of the project to acquisitions or technical services work.

2. Originality and creativity.

3. Clarity and completeness of the proposal.

4. Evidence of an interest in scholarship, such as a previous publication record.

Submission procedure. Brief proposals (five pages or less, double-spaced) should include the following:

1. Description of research, travel, or writing project.

2. Schedule for project.

3. Estimate of expenses (e.g., professional travel, computer time, photocopying, typing.)

4. Recipients of the fellowship will be asked to submit a brief report on the results of their research.

5. An up-to-date curriculum vitae should accompany proposal.

Deadline: December 1, 1993.

\section{PUBLICATIONS OR ARTICLES}

\section{Katharine Kyes Leab and Daniel J. Leab, American Book Prices Current, Exhibition Catalogue Awards}

These awards recognize outstanding catalogs published by American or Canadian institutions in conjunction with exhibitions of books and/ or manuscripts.

Award: A printed citation to the winning institutions organizing the exhibitions. Katherine Kyes Leab and Daniel J. Leab, American Book Prices Current, established an endowment to fund the awards. 


\section{$\begin{array}{llllll}\mathbf{P} & \mathbf{R} & \mathbf{O} & \mathbf{V} & \mathbf{E} & \mathbf{Y}\end{array}$ with OCLC/AMIGOS Collection Analysis Systems.}

Ask for a FREE Collection Analysis CD demo set for results you can see!

amigos@utdallas.edu

800/843-8482

$214 / 851-8000$

\section{$\begin{array}{lllll}\mathbf{P} & \mathbf{O} & \mathrm{I} & \mathrm{N} & \mathrm{T}\end{array}$}

Compare your collection to more than 950 institutions

Melsure effectiveness of your collection derelopment policy

Iustifi budget requests

Evaluate resource sharing opportunities

Support accreditation studies

\section{AMIGOS Bibliographic Council, Inc.}

Eligibility: Catalogs published by American or Canadian institutions in conjunction with an exhibition of books and/or manuscripts which has taken place or which is in progress before August 31, 1993, are eligible. Catalogs must be published between September 1, 1992, and August 31, 1993. The entries will be divided into three budget categories - expensive, moderately expensive, and inexpensive-based upon the production costs as outlined in the entry form. Catalogs may be of varying formats, styles, and scope, but each must represent an exhibition which has taken place. Catalogs may be intended for various types of audiences: e.g., scholars, students, general public. Catalogs may have various purposes: e.g., publicity, dissemination of collection information, attraction of donors, commemoration of a special occasion, etc.

Criteria: Catalogs will be judged on the level of accuracy and consistency of presentation, their clarity, quality of design, and usefulness to the intended audience.

Submission procedure. Four (4) copies of the catalog must be submitted with an entry form (available from the chair of the committee) to the chair: Elaine Smyth, Head, Rare Book Collection, Louisiana State University, Hill Memorial Library, Baton Rouge, LA 70803. All cata- $\log$ submissions will become the property of RBMS. If you have any questions, call Elaine Smyth at (504) 388-6547.

Deadline: September 30, 1993.

\section{K.G. Saur Award for Best Article in College \& Research Libraries}

This recognizes the most outstanding article published in College $\&$ Research Libraries ( $C E R L$ ) during the preceding volume year.

Award: A citation and $\$ 500$ cash to each author donated by K.G. Saur.

Eligibility: Articles published in CERL during the preceding volume year.

Criteria: The winning article will be selected on the basis of originality, timeliness, relevance to ACRL areas of interest and concern, and quality of writing.

Submission procedure. Articles for CERL may be submitted to: Gloriana St. Clair, Assistant Dean for Access Services, E506 Pattee Library, Pennsylvania State University, University Park, PA 16802.

\section{Rare Books \& Manuscripts Librarianship Award}

This award stimulates the contribution of articles of superior quality to the ACRL journal 
Rare Books and Manuscripts Librarianship (RBML).

Award: $\$ 1,000$ cash to an author and a citation donated by Christie, Manson \& Woods.

Eligibility: Article published in $R B M L$ during the two preceding volume years.

Criteria: The winning article will be selected on the basis of significance, originality, timeliness, thoroughness, and pertinence to issues relating to the theory and practice of special collections librarianship. Other criteria will include clarity of thought and expression.

Submission procedure: Articles for RBML may be submitted to: Sidney Berger, University of California, Rivera Library, P.O. Box 5900, Riverside, CA 92521.

\section{RECRUIT THE BEST...}

Academic librarians count on $C \& R L$ News for the latest job information.

Reach a group of outstanding professionals by listing your open positions in $C \& R L$ News.

Contact Jack Helbig, classified ad manager, at 1-800-545-2433 ext. 2513 for help in placing your ad.

Or you can fax your ad to us at (312) 280-7663.

Or mail your ad to us at U21808@UICVM.uic.edu.

And we'll do the rest!

\section{... ADVERTISE YOUR JOB OPENINGS IN C\&RL NEWS}

BIS Bibliographic Instruction Publication of the Year Award

This award recognizes an outstanding publication related to bibliographic instruction published in a given year.

Award. A citation presented by the BIS Awards Committee

Criteria: Publications are judged on the basis of relevance to the field of bibliographic instruction in academic or research libraries, originality, timeliness, and quality of writing.

Eligibility: Publications include journal articles, books, and book chapters. Submitted publications may be authored by one or more individuals, a group, organization, or committee. BIS publications are not eligible for consideration for the award. Publication year is defined as September through August of the year preceding the year the award is given.

submission procedure: Submit a two-page summary, a copy of the publication, and nomination form (available from the committee chair) to: Karen William, Committee Chair, Central Reference Library, University of Arizona, Tucson, AZ 85719; (602) 621-4865.

Deadline. December 1, 1993.

\section{Oberly Award for Bibliography in Agriculfural Sciences}

The Oberly Award was established in 1923 in memory of Eunice Rockwood Oberly. This biennial award is given in odd-numbered years for the best English-language bibliography in funded by the U.S. Agricultural Information Network, the Agway Foundation, Associates of the National Agricultural Library, the Council on Botanical and Horticultural Libraries, and the Cargill Information Center.

Eligibility: English-language bibliographies in the field of agriculture or a related science compiled during the two-year period preceding the year in which the award is made.

Criteria: Bibliographies submitted for award consideration are judged on accuracy, scope, usefulness, format, and special features: explanatory introductions, annotations, and indexes.

Submission procedure: Nominations may be made in the form of a letter and should point out the reasons the bibliography should be considered for the award. A copy of the bibliography should accompany the nomination. Send nominations to: Mike Haddock, Farrell Library, Kansas State University, Manhattan, KS 66506.

Deadline: December 1, 1994. 